\title{
13. MMORPG as Locally Realized Worlds of Action
}

\author{
Laurent Di Filippo
}

Boni, Marta (ed.), World Building. Transmedia, Fans, Industries. Amsterdam University Press, 2017

DOI: $10.5117 / 9789089647566 / \mathrm{CH} 13$

\begin{abstract}
This paper addresses the question of concrete realizations of imaginary worlds as situated worlds. As a case study, the author bases his reflections on Age of Conan: Hyborian Adventure, an MMORPG based on the adventure of Conan the barbarian, the character created by Robert E. Howard in the 1930s. The author of the paper uses Erving Goffman's theory of game and the notions of "locally realized world" and "membrane" to address this situated production. He then discusses the place of the player and the relations to the representations in the game as a vicarious experience and a distance implied by playful practices. By crossing several works of Erving Goffman, the author shows that immersion in gaming worlds is the product of both being absorbed in the action and maintaining a distance with it in order to be at the same time an actor and a spectator of the action.
\end{abstract}

Keywords: MMORPG, Action, Immersion, Transmedial World, Conan

While younger than other forms of expression, video games have gained much popularity in the last few decades. They are now often part of broad multi-platform commercial strategies and, thereby, offer specific actualizations of fictional worlds that appear on various media (as also seen in the previous chapter).

Within the framework of the recent "world" trend in media studies (Ryan and Thon 2014, 1), I suggest to consider another point of entry to the study of "worlds", borrowing thoughts from the sociologist Erving Goffman and crossing perspectives about games and world building. This work aims to show how a game can be a specific actualization of a world in 
an interactionist sociological sense and what place it has in a transmedia environment. As a case study, I will take Age of Conan: Hyborian Adventures, a Massively Multiplayer Online Role Playing Game (MMORPG) ${ }^{1}$ developed by the Norwegian company Funcom. ${ }^{2}$ This game is based on the stories about Conan, the famous barbarian invented by the Texan author Robert E. Howard, one of the founding fathers of the fantasy genre (Besson 2007, 100; Parsons 2015, 58).

The chapter is organized in three progressive steps. First, taking game as an example, I will characterize a medium as a particular manifestation of a fictional world which I call a locally realized world and propose another path to study the limits of a gaming situation. Second, I will study the specificities of games as places of action. Third, I will show how the preceding developments lead to the question of immersion. In my conclusion, I will extend my reflections to a broader research question about permanence and change.

\section{Imaginary worlds and situated worlds}

Age of Conan: Hyborian Adventures is an MMORPG based on Robert E. Howard's work. The game is not merely a copy but rather an adaptation of the author's texts. This simple idea points out a twofold characteristic of the game as existing at the same time in relation with older cultural material and as a specific actualization and expression of this material. Its world is reinterpreted to give the players an experience which is different from reading the texts. In more theoretical terms, studying games associated with a network of productions raises issues concerning the balance between "convergence" and "fragmentation" (Ludes 2008, 10) or "convergence" and "divergence" (Ryan and Thon 2014, 3). Broadly stated, it is part of a reflection about unity and diversity, or permanence and change, within media franchises. Questions that arise can be formulated as such: should one consider that the world one experiences through various media productions of a franchise is always the same? And, if not, what relations and differences exist between those productions?

One first needs to define the notion of "world" in a gaming situation to understand, from an interactionist point of view, what an MMORPG such as Age of Conan represents as part of a transmedia franchise. The definition of "world" can vary greatly in social sciences and in the humanities. All uses of the word are not compatible, but, instead, they offer various angles for studying social and human phenomena depending on the academic discipline and the scientific interests of researchers. ${ }^{3}$ In literature and media 
studies, "imaginary worlds" are often considered as "secondary worlds" built by individuals living in the "primary world". In his recent book, Mark J.P. Wolf sees each medium as a window opening onto a secondary world (Wolf 2012, 248). This implies worlds existing beyond the medium that presents them. A similar idea of distinction is also present in T.L. Taylor's work, when she says that players "play between worlds", which means "playing back, and forth, across the boundaries of the game world, and the 'real' or nonliteral game space" (Taylor 2006, 17). Thereby, Taylor takes over the divide between online and offline world.

The main difficulty with these theories is that they set apart the primary and the secondary worlds as they oppose the real and the imaginary worlds, sometimes labelled as a distinction between "real" and "virtual" or "game" and "ordinary life". In my opinion, however, this conception does not help to understand some characteristics of Man in the anthropological and sociological sense. One can wonder how real a fictional world is as it has concrete material manifestations and is the result of production and reception activities. How can we consider the reality of the experience of a fiction?

\section{Transmedial worlds and world-building activities}

Robert E. Howard's short stories about Conan appeared in the pulp magazine Weird Tales in the first half of the 1930s. Those stories were later re-published in books, anthologies, and nowadays on the Internet. Other authors followed his works and wrote stories about Conan. Numerous productions like comics, games, and films, relate to the franchise (Bertetti 2014). Each production expresses resources that are part of a broader set that forms the "imaginary world" of Conan and allows one to apprehend this world in specific mediated forms. Recently, Paradox Entertainment has bought the rights to the Conan trademark, ensuring a degree of coherence between products. ${ }^{4}$ It can then be labelled as transmedia exploitation. Paolo Bertetti has recently suggested to study productions of the Conan franchise from a character-centered approach instead of a world-centered approach. Nevertheless, the recent collection of novels from the Age of Conan collection, which feature other heroes, and the MMORPG, which borrows many elements from them, participate in developing the Hyborian world beyond the famous barbaric character's original incarnation.

As Christy Dena $(2009,16)$ has shown, definitions of transmedia vary. Unlike Henry Jenkins, who favors additivity of content upon redundancy in 
transmedia franchise (Jenkins 2006, 98), Lisbeth Klastrup and Susana Tosca see adaptations as possible processes of transmedia construction. They argue that "transmedial worlds are abstract content systems from which a repertoire of fictional stories and characters can be actualized or derived across a variety of media forms" (Klastrup and Tosca 2004, 1). ${ }^{5} \mathrm{~A}$ transmedial world lies in the mental construction of the actors and not in its material entity (see also: Klastrup and Tosca 2012, 48; Klastrup and Tosca 2014, 297). If their idea of abstract construction helps to understand some mental subjective processes, their work can be completed by an analysis of local actualizations of resources that compose what they call the "repertoire" of such a transmedial world. For example, Howard's writings present several countries and kingdoms that are part of Conan's world repertoire, but only some of them will be used within the MMORPG.

Goffman's theories about games should help to define such local actualizations more thoroughly. In his book Encounters, dedicated to the study of "focused interaction", he proposes to analyse social situations and the implication of actors. In the first essay, called "Fun in Games", he refers to Gregory Bateson's analysis of play as a "frame" of mind that participates in constructing the meaning of a situation (Bateson 1955; Goffman 1961, 20). ${ }^{6}$ The sociologist also mentions Kurt Riezler (1941) who analyses what is meant by "merely playing" in order to understand how people differentiate play and seriousness. According to Riezler, the answer lies in the "horizon" of the activity, which is the limit of possible consequences. Therefore, individuals will not build causal relations with broader life when they "merely play" (Riezler 1941, 517), and "the game is a little cosmos of its own" (Riezler 1941, 505). Goffman follows Riezler when saying that "games, then, are worldbuilding activities" and applies this idea to all possible social situations (1961, 27). Each gathering of people creates "a world of meaning" (Goffman 1961, 27) in which people act according to the relevance of the situation. He defines the order of an encounter as "a locally realized world of roles and events" that "cuts the participants off from many externally based matters that might have been given relevance, but allows a few of these external matters to enter the interaction world as an official part of it" (Goffman 1961, 30).

Goffman's idea of a world here is therefore not the same as the world of literary studies. Saying that Robert E. Howard's Hyborian Age as well as Tolkien's Middle-earth are imaginary worlds does not lean on the same definition of the polysemic notion of world as saying that a card game is a "world of role and events" as Goffman uses this notion; that is to say: a specific situation providing a meaningful context to the identities and actions of the participants. Nevertheless, his work should help to characterize 
the relation established between social actors and specific expressions of a fictional universe.

\section{Locally realized worlds}

Goffman argues that a sense of reality emerges from the meaning given to the elements that are parts of a situation. This process participates in constructing realized resources that he defines as "locally realizable events and roles" based on the material that is available at hand for the actors (Goffman 1961, 28).

In an MMORPG, characters (playable or non-playable), areas, landscapes, monsters, objects, the interface, and all elements, activities, and processes are realized resources as long as they are relevant to the situation at hand. Let's just take one example: Age of Conan: Hyborian Adventures' timeline follows the novel The Hour of the Dragon, in which Conan is the king of Aquilonia. In the game, player-characters can meet this main figure in the castle of Tarantia, the capital of Aquilonia. A researcher can study this character as a "realized resource" in order to analyse various processes, such as his visual and audio representations, his role in various quests, his relations to other characters, how players can interact with him, etc.

Following Goffman, I therefore propose to call the actualization of a particular world during a situation a locally realized world. This concept includes acts of production, the materiality of the media, and its receptions. Stressing the difference between "imaginary worlds" and "realized worlds" allows us to reflect upon expressed resources. Each manifestation of the world must then be considered through the way it expresses the imaginary world, makes it tangible and opens it to interpretation. Marie-Laure Ryan and Jan-Noël Thon talk about "represented worlds" that are "sites of creative activity in which cultures elaborate their collective social imaginary" (Ryan and Thon 2014, 19), thus questioning the link between imagination and its concrete manifestations. Playing is therefore not the only way of experiencing locally realized worlds. The work of game developers also constitutes realized actions of the game production process. In a broad sense, researchers should look at how expressed resources match the relevance of various situations depending on the social actors' activities. The situation also defines the data that researchers are able to gather for their study by making them observable.

Moreover, the locally realized world is not just a fixed occurrence, but part of a dynamic process. When a player-character becomes stronger, 
some situations, like fighting enemies, become easier for him or her. Being a first-level beginner or a high-level experienced character does not involve the same resources. Changes also occur at the level of the product: contents, such as new territories or quests, are added through updates; game mechanisms change; seasonal events occur. There is an evolution through time and locally realized worlds should be considered more specific than the game in general.

\section{Limits of the realized world and transmedia: membrane and transformation rules}

The "local" aspect of realized worlds questions the definition of the limits of a social situation. Discussions about the boundaries of games in video games studies have often (perhaps too often?) been based on the works of Johan Huizinga (1951) and Roger Caillois (1958) and on the notion of "magic circle" that the former is supposed to have forged in his book Homo Ludens (Copier 2009). As Eric Zimmerman (2012) explains, this misconception is due to an interpretation of his own book Rules of Play, written with Katie Salen (Salen and Zimmerman 2004). Scholars too often agitate the "strawman" of the magic circle to counter the idea that a game is separated from the rest of the world, ${ }^{7}$ even if Huizinga himself underlined that a game has a function for the community in which it is played. Play should then not be considered as fully separated from the rest of the world, but instead, as having a specific place among other activities (Di Filippo 2014).

Erving Goffman offers another starting point to study the limits of a situation and its relations to other social activities. The Canadian sociologist proposes to talk about a membrane and explains his choice: "In order to think more easily in these organic terms, an organic metaphor might be attempted. A living cell usually has a cell wall, a membrane, which cuts the cell from components in its external milieu, ensuring a selective relation between them and the internal composition of the cell" (Goffman 1961, 65). Using this metaphor, he argues that each interaction situation has its specific relevance and internal consistency and is at the same time in relation with a broader context. This duality must be kept in mind when studying social interactions. Taken as such, social situations have to be understood through the links that they build with other social activities. As he argues, "the dynamics of an encounter will be tied to the functioning of the boundary-maintaining mechanisms that cut the encounter off selectively from the wider world" (Goffman 1961, 66). ${ }^{8}$ 
In her article about pervasive games, Eva Nieuwdorp (2005, 6-7) proposes to shift from the idea of "magic circle" to Goffman's conception of "membrane", stressing three main elements in his theory: rules of irrelevance, transformation rules, and realized resources. These three elements help set a frame "around a spate of immediate events" (Goffman 1961, 20), as Vinciane Zabban $(2011,14)$ points out. ${ }^{9}$ In Synthetic Worlds, Edward Castronova (Castronova 2005, 147, 159) also uses the metaphor of a "porous" membrane to talk about the limits of the games, without quoting Goffman or addressing the question of the transformations that occur when a resource is actualized in the game. ${ }^{10}$

Goffman also presents two sorts of "boundary-maintaining mechanisms": "rules of irrelevance" (Goffman 1961, 19) and "transformation rules" (Goffman 1961, 29). The first set of rules can be defined as "the selective disregard of all practices and objects that normally have a meaningful place in the life world domain, but which are not in keeping with the cultural conventions that apply to the world of the game" (Nieuwdorp 2005, 7). For example, the physical strength of a player is not relevant to play Age of Conan, but does matter when moving a flat. The second set of rules expresses the fact that individuals adapt resources to match the relevance of the situation: "the transformation rules of an encounter describe the fate of any property as a constituent of internal order" (Goffman 1961, 33). Elements of the texts written by Howard about Conan, such as characters, landscapes, and monsters, are adapted visually in the MMORPG to appear on the computer screen. Rules of irrelevance and transformation rules are two faces of the displacement of resources typical of world-building phenomena, as "during the move from one medium to another, forms of mediation may be lost or gained, causing the material of a story or world to be changed" (Wolf 2012, 250).

Both sets of rules define continuities and changes between locally realized worlds and set the ground for a transmedial world. Transformed realized resources are the basis for the recognition of those worlds. Such a mental construction is made of all connections that individuals build between realized worlds. Where those relations are absent, gaps can still be filled by interpretation (Wolf 2012, 51). The re-enactment of a scene from Howard's short story The Frost-Giant's Daughter as a quest in the MMORPG can be taken as an example. Ymir's daughter Atali appears on a battlefield and lures the "player-character"11 (Di Filippo 2012) into the same ambush as Conan in the short story: she will have to fight against two frost-giants before Atali finally disappears. The player-character takes the place of Conan in the narrative structure and becomes the hero. 
Putting the player-character at the centre of the story is a transformation rule that defines a specificity of the MMORPG. More importance is given to the user. Intertextuality, articulated with a shift of point of view from reader to player, reveals how the designers intend to bring the consumer to experience the world and the adventures of Conan. Designers also call on the player's knowledge of the short story to understand the references. Mark J.P. Wolf has already proposed four types of transformations within the frame of transmedial expansion: Description, Visualization, Auralization, Interactivation/de-interactivation (2012, 250-264). In an MMORPG like Age of Conan, these rules must not be taken separately, but one has to take into account their articulation: a frost-giant is adapted from a textual source into a visual form, the encounter with such a being produces sound effects, and the "player-character" (PC) interacts with it, often through fighting.

To complete the understanding of such phenomena, we need to take a more radical interactionist point of view than Goffman does. The sociologist still opposes a situation like gaming to the "wider world". But the wider world is also made up of social interactions: working, being at the gym, shopping, going out... All constitute a wide range of situations that have to be distinguished from one another. Reading a Conan story certainly relates more to the construction of the imaginary world of the MMORPG than eating dinner, but the latter may participate in defining a temporal schedule in the player's agenda. A mealtime can therefore be considered as sociologically relevant in a study about game practices and time schedule organization.

The metadiscourse about the productions also contributes to bridging various locally realized worlds and to the constitution of a feeling of continuity between them. Paratext and commercial discourse (all information around the game, such as advertising, information on the official and unofficial websites, the name on the box, and the login screen) can be considered locally realized resources in a situation of informing, advertising, or promotion. In 2005, Funcom announced Age of Conan, a project based on Robert E. Howard's stories..$^{12}$ Before the game was launched, the commercial discourse already participated in defining a future gaming situation. Despite the fact that numerous elements in the game are borrowed from works of his continuators, like John Maddox Roberts among others, only Robert E. Howard is generally mentioned. The reputation of the original creator and faithfulness to his work are used to promote the game and give a feeling of continuity between works considered as canonical, the writings of Howard, and later adaptations, like those of his continuators. 


\section{The game world as a place of action}

\section{Action and uncertainty}

Age of Conan was first presented as an "Online Action Role Player Game". ${ }^{13}$ This category is often used for games that are more dynamic and combat-oriented than turn-based $\mathrm{RPG}^{14}$ and relates to Conan's world being presented as very brutal, dark and mature compared to other fantasy settings. Gaute Godager, the first game director, said in an interview: "For if it's one thing which is true about Conan is that it is no ordinary fairytale, but a brutal, lustful, lush and sinful universe made by grown-ups, for grown-ups." ${ }^{\prime 5}$ Action and violence are then related and seem to be at the heart of the game.

Erving Goffman addresses the question of "action" in his essay "Where the action is" (Goffman 1967). He observes that the term "action" appeared in the American society in a "non-Parsonian sense" (Goffman 1967, 149). Parson defines action as structures and processes that help to form meaningful intentions and implement them, which means that everything that people do is then considered as an action (Handler 2012, 182). By contrast, Goffman's use of the term rather refers to an opposition between situations where there is action and situations where there is none. As Richard Handler (Handler 2012,181 ) explains, this essay is first of all "about the meaning of the term action in the American society" and highlights "his use of native terms as analytic terms" (Handler 2012, 188). Goffman's work is then an analysis of the social organization of society through the use of a linguistic category that we also find in the naming of the game genre.

His text highlights sociological problems about decision-making and choice in situations of high uncertainty where information is lacking. According to him, "wheresoever action is found, chance-taking is sure to be" (Goffman 1967, 149) and "for chanciness to be present, the individual must ensure he is in a position (or be forced into one) to let go of his hold and control the situation, to make, in Schelling's sense, a commitment. No commitment, no chance-taking" (Goffman 1967, 152). Thomas C. Schelling (1960) borrows Morgenstern and Von Neumann's game theory in order to understand international geopolitical affairs. Goffman met and worked with the economist and thus "strengthened his understanding of game theoretic accounts of human behaviour" (Fine and Manning 2003, 36). ${ }^{16}$ His analysis leads him to propose that "action is to be found wherever the individual knowingly takes consequential chances perceived as avoidable" (Goffman 1967, 194). He opposes it to "uneventful moments" which 
"have been defined as moments that are not consequentially problematic. They tend to be dull and unexciting" (Goffman 1967, 174). "Places of action", as he calls them, offer to experience situations of uncertainty and "fatefulness".

\section{Fatefulness and vicarious experience}

Goffman included many kinds of activities during which uncertainty occurs, like games, casinos, but also movies in a vicarious way. Video games were not yet as popular as they are today, but they fit in his description as they offer chance-taking and commitment. Games in general can be considered more action-oriented than other media, like movies or books. One does not roll dice when reading Howard's short stories to know if Conan will kill his enemy or not. But in an MMORPG such as Age of Conan, randomness mechanisms are at the center of the gameplay.

According to Goffman, society has curtailed fatefulness, in a heroic and dutiful sense, from civilian life; that is to say, society has taken away from people the possibilities to show their character, as moral quality and values (Goffman 1967, 193). As a consequence, places where it is possible to confront uncertainty in a "vicarious" way to reaffirm one's character appear to compensate for this loss. ${ }^{17}$ In places of action, "the individual brings into himself the role of performer and the role of spectator; he is the one who engages in the action, yet he is the one who is unlikely to be permanently affected by it" (Goffman 1967, 198). Riezler's idea of "merely play" as an inconsequential activity appears again. An MMORPG like Age of Conan offers numerous possibilities to make commitments, to let go of his hold and to take a chance: combat, raiding parties, looting, PVP sessions, etc. At the same time, the player will never be hurt physically like the character, nor will she die. Nevertheless, players invest time, dedication, and emotions into the activity and they act in accordance to the gaming situation. The involvement in the situation is therefore entirely real.

Places of action are real in the sense that they offer situations during which individuals can express and define qualities that cannot be shown otherwise, leading to the question of social organization:

Whatever the reasons why we consume vicarious fatefulness, the social function of doing so is clear. Honorable men in their scenes of fatefulness are made safely available to all of us to identify with whenever we turn from our real worlds. Through this identification the code of 
conduct affirmed in fateful activities - a code too costly or too difficult to maintain in full in daily life — can be clarified and reasserted. A frame of reference is secured for judging daily acts, without having to pay its penalties. (Goffman 1967, 266)

Individuals can grasp a bit of the feeling of uncertainty that is sufficient to reactivate social values:

Looking for where the action is, one arrives at a romantic division of the world. On one side are the safe and silent places, the home, the wellregulated role in business, industry, and the professions; on the other are all those activities that generate expression, requiring the individual to lay himself on the line and place himself in jeopardy during a passing moment. It is from this contrast that we fashion nearly all our commercial fantasies. (Goffman 1967, 268)

Places of action offer a "commercialized vicarious experience" (Goffman 1967, 262), since "commercialization [...] brings the final mingling of fantasy and action" (Goffman 1967, 269). Cultural industries' productions compensate the loss of expressive ways for action and social values. Consuming fiction is not considered as separate from the rest of life, but as a specific expression of social representations.

Age of Conan is depicted as a dark, violent, and mature game and therefore expresses ideas about darkness and violence. The finishing moves, when a player-character makes a critical hit and kills an enemy, illustrate this idea. The killing is more violent than regular hits, like tearing the enemy's head off with bare hands, happens in a movie-like mise-en-scène and blood is spread on the screen ${ }^{18}$. In such video games, the values are not always those of the "honorable men" of Goffman's time, but games still convey social values and allow expressions that are forbidden in other kind of situations. In a sense, gameplay is a way of expressing a certain code of conduct that is not allowed elsewhere.

In return, the values expressed in fictional situations interrogate moral values and codes of conduct in our societies by taking into account the frame in which they are expressed. That is why, contrary to what Jessica Langer says about otherness and stereotypes which "continue to proliferate within online discourse" (Langer 2008, 101), one must always study such expression according to the transformation rules occurring between various situations, which set a frame around them and which individuals are mostly well aware of. 


\section{Action, "worldness," space and time}

A look at the game's implementation of geographies and territories shows that MMORPGs are built to bring action to the players and ties our study to the notion of world: "one of the key elements of virtual worlds is the 'worldness' or spaces they create for participants" (Consalvo 2011, 330). Nevertheless, those terms are "metaphors" that seem to "fit our new experiences" linked to the idea of "cyberspace" (Consalvo 2011, 330). In other words, game worlds are representations that induce the idea of a world.

Defending a ludological approach, Espen Aarseth said about World of Warcraft's world that "in Azeroth [...] the distances are surprisingly small, indicative of the fact that this is in fact no fictional world, but rather a functional and playable gameworld, built for ease of navigation" and adds "Azeroth is about playability. Tolkien's world is not designed for play, and fictional travel time can contain gaps where readers are spared the boredom of the main character putting one foot in front of another for days or months without much else happening" (Aarseth 2008, 118). In other words, WoW proposes situations of chance-taking and action, but limits uneventful moments.

Age of Conan is an adaptation of a series of texts in which the world is a pre-cataclysmic version of Earth. Robert E. Howard drew a map of the Hyborian Age superimposed on a map of Europe. His world would be several millions of square kilometres large, which is impossible to render in a game such as Age of Conan. A selection was made, and only small portions of the world are represented as three-dimensional spaces. Those regions concentrate the action of the game: quests, monsters, dungeons, etc. Other places presented in different Conan productions are absent. ${ }^{19}$ This limitation confirms the idea of a locally realized version of the world of Conan and, in Aarseth's sense, Age of Conan is therefore "functional and playable".

Moreover, the game is what designers and players call "instanced": territories are separated from one another, long travel times between regions are replaced by loading screens, and regions can be replicated when the number of players is to high in order to avoid the game to slow down.

Rhetorically, to call something a world is to give it a privileged status as a self-contained, autonomous entity. As we have seen, the "world" in World of Warcraft is not a proper world, or even a fictional one, but a "world" in the theme park or zoo sense, a conglomerate or parkland quilt of connected playgrounds built around a common theme. (Aarseth 2008, 121) 
This description could also fit Age of Conan as available territories are made to propose action to the players. But we have to disagree on the fact that "in multiplayer games, space-time cannot be individually flexible, but is, in fact, objective and continuous. The players form an in-game community of social, localized agents, and this living structure cannot be overruled by the temporal lacunas and spatial montages common in works of fiction" (Aarseth 2008, 118). As Age of Conan illustrates, there are ellipses and loading pages during travelling time for some players, while others stay in one region, maybe fighting or chatting. Then, contrary to what Aarseth says about World of Warcraft, the experience of space and time in Age of Conan is subjective and individually flexible.

\section{Immersion}

According to Frank Rose $(2011,8)$, people want to be immersed to make their own story. But the use of that metaphor conveys the idea of entering another world. As Marie-Laure Ryan says, discourses about technologies and virtual reality created "a hype fuelled by the hope that the computer could physically transport us into alternate realities" (Ryan 2006, 634).

Goffman's "Fun in Games" and "Where the action is" offer two different points of view about immersion. In the first, Goffman says that "euphoria arises when persons can spontaneously maintain the authorized transformation rules" $(1961,66)$. The mental state of being focused is crucial and that is how "being absorbed" occurs (Goffman 1961, 69-70). In the second, he argues that some distance is established between individuals and the situation that is represented. They never fully confront fatefulness, but nevertheless, "vicarious experience re-establishes our connection to values concerning character" (Goffman 1967, 268). Despite the fact that the relation to fatefulness is indirect and mediated, it is sufficient to reassert a code of conduct and values.

On the one hand, Goffman argues in favor of the attachment to the rules of transformation. Participants have to accept the reality of the situation, even if it is fictional. On the other hand, he argues in favour of non-consequential participation. The two points of view are not opposed, as they do not apply to the same dimension of the situation. Both are about boundary-maintaining mechanisms. The first is about cutting oneself from external disturbances because "incidents" can cause "flooding out" (Goffman 1961, 45-6o). The second is about keeping a safe distance from fatefulness. Immersion can then be understood in terms of boundary-maintaining processes that necessitate focusing without risking any danger for the player. 
Nevertheless, these ideas deserve some critique. Players take part in diversified situations when playing the same game hundreds, even thousands of hours. MMORPGs offer various activities like quests, player versus player fighting (PvP), crafting, high-level raiding, etc. These activities do not demand the same kind of involvement. High-level raiding often requires more concentration than gathering resources for crafting. Yet, both types of playing are part of the game. Players can sometimes be deeply focused on the action, without losing sight of the fact that they are playing a fictional game, sometimes they are more relaxed. Researchers should then take into account the various types of activities and the experience of players facing different situations. The notion of immersion alone is not relevant enough to address the relations that individuals have when interacting with a medium or other people during a game situation.

Furthermore, Kurt Riezler noticed a kind of detachment that play induces when one defines a situation as merely playing (Riezler 1941, 506-507). However, he notes that not everyone adopts the same attitude toward a game. A football champion can take a match very seriously because it is part of his professional career. According to Riezler, "playful attitude" means detachment from the consequences. Therefore, games and ordinary life define a kind of social organization, but they do not imply a corresponding playful or serious attitude, as someone can take a game seriously or ordinary life as not serious at all.

Following another lead, one could use the concepts that Mark J.P. Wolf suggests in his chapter in this book: "absorption", in order to understand how social actors seize elements of imaginary world; "saturation", as a limit of the amount of information that someone can grasp, and "overflow", which symbolizes the fact that when the amount of information is too high, individuals tend to group them in a process of "chunking". Such concepts could be used in order to study how knowledge about an imaginary world at the same time is spread and varies among people depending on their individual experiences.

\section{Conclusion: permanence, change, and media studies}

The preceding discussions lead to more general reflections about permanence and change, which join up with questions about determinism and freedom. Goffman was neither a structuralist, nor a radical interactionist, as he explains in his presidential address (Goffman 1983). According to him, meaning is not fully imposed by larger social structures, but emerges 
from the order of the situation (Rawls 1987; Rawls 1988). Studying relations between media and locally realized worlds of a franchise has shown that the order is never solely the result of the situation. It is based on previous expressions that provide resources that will be transformed, following rules of irrelevance and transformation rules, in order to match a new relevance. One should complete Goffman's views by saying that the internal meaning is not fully constituted by the interaction, but emerges during a specific situation by its internal order and the relations constructed with other situations taken in a broader context. Some structures and systems of relations (Wolf 2012, 153-197) are similar among various manifestations and support the abstractions that are necessary to build a continuity between them. At the same time, "rules of irrelevance" and "transformation rules" bring change into the situation.

Video games and, as places of action, MMORPGs more specifically, have a specific place in transmedia franchising. They offer possibilities to confront fatality and uncertainty and to experience an imaginary world from an active place, as they allow players to be actors and spectators at the same time. In that sense, negotiating the boundaries of an imaginary world when playing does not involve the same mechanisms of immersion as other media and researchers should therefore focus on the ways in which imaginary worlds are always locally realized. Therefore, transmedia franchises and multi-platform world building offer relevant case studies in order to address questions about permanence and change in culture. They constitute new objects while renewing concerns about old questions that still deserve interest from researchers.

\section{Notes}

1. MMORPG is a genre of multiplayer video games in which a large number of players, hundreds or even thousands, play simultaneously on servers across the Internet. Researchers have stressed the ideas of shared space and persistence of the world, meaning that servers are usually available $24 / 7$ (Consalvo 2011, 326).

2. The length of this chapter does not allow me to make an extensive description of the gathered data. Nevertheless, it is important to mention that this text is based on an two-year long ethnography of Age of Conan, between 2010 and 2012, and is part of an on-going PhD thesis.

3. From the philosophy of "possible worlds" (Ryan 2006; Wolf 2012, 17) to empirical "social worlds" as Howard S. Becker presented in his study about "art worlds", one can find the "world of daily life" of sociological phenomeno- 
logy (Schütz 1962, 208), "fantastic worlds" (Rabkin 1979), and "other worlds" (Timmerman 1983, 49) of fantasy literature, "game worlds" (Taylor 2006, 151), "virtual worlds" (Consalvo2011, 326; Boellstorff, Nardi, Pearce and Taylor 2012) or "synthetic worlds" (Castronova 2005) to talk about digital games; "storyworlds" (Ryan and Thon 2014) when it comes to narratology, just to name a few examples that can be relevant for us.

4. Personal interview with Joakim Zetterberg. Some of the stories of REH are now in the public domain and are not the property of Paradox Entertainment.

5. The whole definition is: "Transmedial worlds are abstract content systems from which a repertoire of fictional stories and characters can be actualized or derived across a variety of media forms. What characterises a transmedial world is that audience and designers share a mental image of the 'worldness' (a number of distinguishing features of its universe). The idea of a specific world's worldness mostly originates from the first version of the world presented, but can be elaborated and changed over time. Quite often the world has a cult (fan) following across media as well" (Klastrup and Tosca 2004).

6. The disparity of Goffman's work does not always make continuity between his texts obvious (Smith 2006, 5). Nevertheless, this essay provides examples for his article "The neglected situation" (Goffman 1964, 135) and lays the foundations for his famous book Frame Analysis (Goffman 1974). The idea of transformation in the geometrical sense appear in both texts and leads him to the idea of "keying" (Goffman 1961, 33; Goffman 1974, 40-82).

7. One recent example of such misuse of Huizinga's work is Mia Consalvo's article "There is no magic circle" (Consalvo 2009).

8. Some years later, in his book Interaction Rituals, he defines a conversation interaction with the same terms: "a little social system with its own boundary-maintaining tendencies” (Goffman 1967, 113).

9. Unfortunately, neither Nieuwdorp nor Zabban take into account Riezler's influence on Goffman.

10. In an endnote, he thanks F. Randall Farmer for suggesting the term (Castronova 2005, 301).

11. In a MMORPG, a player-character is the entity based on the association between a player and its character.

12. http://www.businesswire.com/news/home/20050420005393/en/FuncomAnnounces-Age-Conan---Hyborian-Adventures\#.VMtlIy6KJsc. Accessed 30 January 2015.

13. http://www.businesswire.com/news/home/20050420005393/en/FuncomAnnounces-Age-Conan---Hyborian-Adventures\#.VM5UwC6KJsc. Accessed 1 February 2015.

14. A turn-based RPG is a Role Playing Game in which players take turns while playing, by opposition with real-time games where players play simultaneously.

15. Gaute Godager, Interview Tothegame.com, published 4 May 2006. http:// www.tothegame.com/interview.asp?gameid=2318. Accessed 22 July 2014. 
16. This influence is also remarkable in the essays published two years later in his book Strategic interaction (Goffman 1969), which is considered as the most oriented toward the rational actors model of his works.

17. In his book about world building, Mark J.P. Wolf also present fictional world as offering a "vicarious experience" (Wolf 2012, 28).

18. The game also has less cartoonesque graphics than other games, like World of Warcraft, and some explicit sexual content is present.

19. They are not completely absent as they appear on the ingame map, but they are not present as three-dimensional environments.

\section{Works Cited}

Aarseth, Espen. 2008. "A Hollow World: World of Warcraft as Spatial Practice." In: Digital Culture, Play, and Identity. A World of Warcraft Reader, edited by Hilde G Corneliussen and Jill W. Rettberg, 111-122. Cambridge/London: MIT Press.

Bateson, Gregory. 1955, 1972. "A theory of play and fantasy." In: Steps to an Ecology of Mind, 177-193. New York: Ballantine.

Becker, Howard Saul. 1982. Art worlds. Berkeley: University of California Press.

Bertetti, Paolo. 2014. "Conan the Barbarian: Transmedia Adventures of a Pulp Hero." In: Transmedia Archeology: Storytelling in the Borderlines of Science Fiction, Comics and Pulp Magazines, edited by Carlos Scolari, Paolo Bertetti, and Matthew Freeman, 15-38. Basingstoke: Palgrave Macmillan.

Besson, Anne. 2007. La fantasy. Paris: Klincksieck.

Boellstorff, Tom; Nardi, Bonnie; Pearce, Celia; and Taylor, T.L.. 2012. Ethnography of Virtual Worlds. A Handbook of Method. Princeton/Oxford: Princeton University Press.

Caillois, Roger. 1958, 1967. Les jeux et les hommes. Le masque et le vertige. Paris: Gallimard.

Castronova, Edward. 2005. Synthetic Worlds: the business and culture of online games. Chicago/London: University of Chicago press.

Consalvo, Mia. 2009. "There is no Magic Circle." Games and Culture 4 (4): 408-417. Consalvo, Mia. 2011. "MOOs to MMOs: The Internet and Virtual Worlds." In: The Handbook of Internet Studies, edited by Mia Consalvo and Charles Ess, 326-347. Malden/Oxford: Wiley-Blackwell.

Copier, Marinka. 2009. "Challenging the magic circle. How online role-playing games are negotiated by everyday life." In:Digital material: Tracing new media in everyday life and technology, edited by Marianne van den Boomen, Sybille Lammes, Ann-Sophie Lehmann, Joost Raessens, and Mirko Tobias Schäfer, 159-171. Amsterdam: Amsterdam University Press. 
Dena, Christy. 2009. Transmedia Practice: Theorizing the Practice of Expressing a Fictional World Across Distinct Media and Environments. Phd diss., University of Sydney.

Di Filippo, Laurent. 2012. "Les notions de personnage-joueur et roleplay pour l'étude de l'identité dans les MMORPG.” ¿Interrogations? Revue pluridisciplinaire en sciences de l'homme et de la société 15. http://www.revue-interrogations.org/ Les-notions-de-personnage-joueur.

Di Filippo, Laurent. 2014. "Contextualiser les théories du jeu de Johan Huizinga et Roger Caillois." Questions de communication 25: 281-308.

Fine, Gary Alan; and Manning, Philip. 2003. Erving Goffman. In: Blackwell Companion to Major Contemporary Social Theorists, edited by George Ritzer, 34-62. Malden, MA: Blackwell Publishing.

Goffman, Erving. 1961, 2013. Encounters. Two Studies in the Sociology of Interaction. Mansfield Center: Martino.

Goffman, Erving. 1964. The Neglected Situation. American Anthropologist 66 (6): $133-136$.

Goffman, Erving. 1967. Interaction Ritual. Essays on Face-to-Face Behavior. New York: Pantheon Books.

Goffman, Erving. 1969, 1972. Strategic Interaction. An analysis of Doubt and Calculation in Face-to-Face, Day-to-Day dealings with one another. New York: Ballantine Books.

Goffman, Erving. 1974, 1986. Frame Analysis. An essay on the Organization of Experience. Boston: Northeastern University Press.

Goffman, Erving. 1983. The Interaction Order. American Sociological Review 48 (1): $1-17$.

Handler, Richard. 2012. "What's up, Doctor Goffman? Tell us where the action is!.” Journal of the Royal Anthropological Institute 18 (1): 179-190.

Huizinga, Johan. 1938, 1988. Homo Ludens. Essai sur la fonction sociale du jeu. Paris: Gallimard.

Jenkins, Henry. 2006. Convergence culture: where old and new media collide. New York: New York University Press.

Klastrup, Lisbeth; and Tosca, Susana. 2004. "Transmedial Worlds-Rethinking Cyberworld Design." In: Proceedings of the 2004 International Conference on Cyberworlds, edited by Masayuki Nakajima, Yoshinori Hatori, and Alexei Sourin, 409-416. Los Alamitos, CA: IEEE Computer Society.

Klastrup, Lisbeth; and Tosca, Susana. 2011. "When fans become players: The Lord of the Rings Online in a transmedial world perspective." In Ring Bearers. The Lord of the Rings Online as Intertextual Narrative, edited by Tanya Krzywinska, Esther MacCalum-Stewart, and Justin Parsler, 46-69. Manchester/New York: Manchester University Press. 
Klastrup, Lisbeth; and Tosca, Susana. 2014. "Game of Thrones. Transmedial Worlds, Fandom, and Social Gaming." In: Storyworlds Across Media: Toward a MediaConscious Narratology, edited by Marie-Laure Ryan and Jan-Noël Thon, 295-314. Lincoln/London: University of Nebraska Press.

Langer, Jessica. 2008. "The familiar and the foreign: Playing (Post)Colonialism." In: Digital Culture, Play, and Identity. A World of Warcraft Reader, edited by Hilde G. Corneliussen and Jill Walker Rettberg, 87-108. Cambridge/London: MIT Press.

Ludes, Peter. 2008. "Introduction: Unity in Diversity." In: Convergence and Fragmentation, edited by Peter Ludes, 9-23. Bristol/Chicago: Intellect Books.

Nieuwdorp, Eva. 2005. "The Pervasive Interface: Tracing the Magic Circle.” In: Proceedings of the Digital Games Research Conference-Changing Views: Worlds in Play. Vancouver, Canada. Accessed May 25, 2016. http://www.digra.org/wpcontent/uploads/digital-library/06278.53356.pdf.

Parsons, Deke. 2015.J.R.R. Tolkien, Robert Howard and the Birth of Modern Fantasy. Jefferson: McFarland \& Co Inc.

Rabkin, Eric S. 1979. Fantastic Worlds: Myths, Tales and Stories. Toronto: Oxford University Press.

Rawls, Anne Warfield. 1987. “The Interaction Order Sui Generis: Goffman's Contribution to Social Thoery." Sociological Theory 5 (2): 136-149.

Rawls, Anne Warfield. 1988. "Interaction vs. Interaction Order: Reply to Fuchs." Sociological Theory 6 (1): 124-129.

Riezler, Kurt. 1941. "Play and Seriousness." The Journal of Philosophy 38 (19): 505-517. Rose, Frank. 2011. The Art of Immersion. New York/London: W. W. Norton.

Ryan, Marie-Laure. 2006. "From Parallel Universes to Possible Worlds: Ontological Pluralism in Physics, Narratology, and Narrative." Poetics Today 27 (4):633-674.

Ryan, Marie-Laure; and Thon, Jan-Noël. 2014. "Storyworlds across Media: Introduction." In: Storyworlds Across Media: Toward a Media-Conscious Narratology, edited by Marie-Laure Ryan and Jan-Noël Thon, 1-21. Lincoln, Neb./London: University of Nebraska Press.

Salen, Katie; and Zimmerman, Eric. 2004. Rules of Play. Cambridge/London: MIT Press.

Schelling, Thomas C. 196o. The Strategy of Conflict. Cambridge/London: Harvard University.

Schütz, Alfred. 1962. "On multiple realities." In: Collected Papers I, 207-259. The Hague: Martinus Nijhoff.

Smith, Greg. 2006. Erving Goffman. London/New York: Routledge.

Taylor, T.L. 2006. Play Between Worlds: Exploring Online Game Culture. Cambridge/ London: MIT Press.

Timmerman, John H. 1983. Other Worlds: the Fantasy Genre. Bowling Green: Bowling Green University Popular Press. 
Wolf, Mark J.P. 2012. Building Imaginary Worlds. The Theory and History of Subcreation. New York/Londres: Routledge.

Zabban, Vinciane. 2011. “Ceci est un monde.” Le partage des jeux en ligne: conceptions, techniques, et pratiques, $\mathrm{PhD}$ diss. Université Paris-Est Marne-la-Vallée.

Zimmerman, Eric. 2012. "Jerked Around by the Magic Circle. Clearing the Air Ten Years Later", Gamasutra. http://www.gamasutra.com/view/feature/135063/ jerked_around_by_the_magic_circle_.php.

\section{Media Cited}

Age of Conan: Hyborian Adventures. 2008. Oslo, Norway: Funcom. Massively Multiplayer Online Role Playing Game (MMORPG).

\section{About the author}

Laurent Di Filippo has a PhD in communication Studies and is Dr. des. in Scandinavian studies. He is a member of the Center for Research on Mediations (CREM). His main research area is the use of Norse mythology in contemporary cultural productions and more specifically the Massively Multiplayer Online Role Playing Game Age of Conan: Hyborian Adventures. He is also interested in several fields such as reflexivity in research, transmedia, and the history of social sciences. He is a member of the board of the French open-access peer-reviewed journal Interrogations and has co-edited the books La position du doctorant. Trajectoires, engagements, réflexivité (2012) and Actualité de la question interdisciplinaire en sciences de l'information et de la communication. Expériences de recherches situées (2016). 